\title{
Using the Contingent Valuation Method to Measure Patron Benefits of Reference Desk Service in an Academic Library
}

\section{David W. Harless and Frank R. Allen}

The authors apply a survey technique known as the contingent valuation (CV) method to estimate the economic value that patrons attach to reference desk service in an academic library. The CV method has been used in environmental economics for the past thirty years to estimate the value of environmental amenities. The authors argue that the appropriate measure of patron benefit from reference service includes use value (the usual benefit concept in the library literature) and option value (the benefit to potential users of knowing they have the option of using the services). The survey population consisted of the students and faculty of the academic campus of Virginia Commonwealth University. The authors surveyed 382 students and faculty eliciting willingness to pay (WTP) for reference desk services: WTP to maintain existing hours, WTP to keep the desk open an additional eighteen hours per week; and WTP to add 18.5 more hours (all hours the library is open). The 10 percent trimmed mean (a robust measure of central tendency) indicates that, on average, students are willing to pay $\$ 5.59$ per semester to maintain current hours of the reference desk; instructional faculty indicate they are willing to pay $\$ 45.76$ per year to maintain current hours. Given reasonable assumptions about the cost of service, students and faculty place a value on the current hours of reference desk service that exceeds the cost by a ratio of 3.5 to 1 .

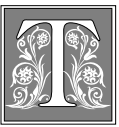

he concept of "just-in-case" reference (the librarian waits at the desk just in case the patron has a question) is receiving increasing scrutiny by library administrators and reference librarians. ${ }^{1,2}$ An entire symposium in the Journal of Academic Librarianship was dedicated to a discussion of the viability of reference services and the pos- sible need for a new model. ${ }^{3}$ But this discussion is occurring without information on the value of reference desk services to patrons. The library literature is replete with cost studies, but few studies consider the benefit to patrons of library services. This is particularly true of reference services where librarians have thoroughly studied the cost of reference transactions,

David W. Harless is an Associate Professor in the Department of Economics in the School of Business Administration at Virginia Commonwealth University; e-mail: dwharles@vcu.edu. Frank R. Allen is Associate Director of the University of Central Florida Libraries; e-mail: fallen@mail.ucf.edu. 
but few have considered the benefits of reference services or how they might be measured.

James R. Kuhlman lays out a general model for conducting cost-benefit analysis of reference services. ${ }^{4}$ He underscores the importance of recognizing that the patron shares part of the cost of obtaining reference services through travel cost (including the opportunity cost of time). Kuhlman does not, however, suggest methods by which the benefit of reference services might be measured. Marjorie E. Murfin's essay contains both a thorough cost analysis of reference service and a discussion of cost-benefit analysis, again without conducting a cost-benefit analysis. ${ }^{5}$ Murfin discusses the willingness-topay (WTP) benefit measure but rejects it. She argues that users may refuse to respond to WTP questions altogether because they refuse to consider paying for a service they were accustomed to receiving for free or believe should be free.

\section{Contrary to the current view in the library literature, use value significantly underestimates the value that patrons place on reference desk services.}

More is said below about the basis and logic of benefit measurement in cost-benefit analysis, but the authors wish to emphasize that when they use the term WTP, they wish to convey the meaning from cost-benefit analysis-the appropriate measure of benefit to individuals. They do not suggest or intend that WTP be the basis for setting prices to patrons for each instance of reference desk service. A costbenefit analysis of a program to improve air quality, for example, would attempt to estimate individuals' WTP for the airquality improvement and then to compare the costs and benefits of the program. But the WTP perspective does not imply assigning per-use prices; as the air-quality example indicates, per-use prices would often be inefficient or impossible.

Paul B. Kantor et al accepted the costbenefit approach and, as part of a larger study, made an attempt to measure pa- trons' WTP and time saved for a single instance of reference desk service. ${ }^{6,7}$ Kantor's study surveyed users as they left the library and asked them to place a value on various library services, including reference desk services. He was surprised at the low value users attach to these services. ${ }^{8}$ Though an intriguing initial attempt to measure the value of reference librarian services, the study was limited because, as the authors explain below, it measured only part of the benefit to patrons of reference services and fell far short of the methodological rigor prescribed by the contingent valuation $(\mathrm{CV})$ method (the correct method for measuring value in this circumstance).

\section{A New Perspective on the Value of Reference Desk Service}

Faculty and students benefit from reference librarian services in a number of ways. Faculty benefit when they receive advice from a reference librarian; they also benefit because they are able to assign projects to students knowing that students will go to the reference desk with questions about how to find and access the resources of the library. Following the environmental economics literature, the authors use the term use value to describe such benefits. In the library literature (e.g., Murfin [1993] and Kantor [1995]), discussion of the benefit of reference librarian services has been restricted to use value. Contrary to the current view in the library literature, use value significantly underestimates the value that patrons place on reference desk services. Use value, correctly measured, indicates the value of reference services to patrons who actually make use of the services. But use value ignores the value to potential users who value the option of seeking expert assistance in the event they require such services. Consider a faculty member at the beginning of an academic year. He or she plans to pursue particular activities over the coming year but recognizes that unforeseen activities are likely to arise. And even for the planned activities, the faculty member may only have a vague idea 
of the particular resources he or she will wish to draw on as the projects evolve. The authors argue that such a faculty member places a value-an option price- on the right to use reference desk services in the event he or she needs them. Hence, even though a faculty member may not use the services of a reference librarian (even for several years), he or she may still place significant value on the right to use those services.

\section{Consider first that reference desk services (as well as other library services) may be viewed as a quasi- private good, such as environmental amenities.}

The notion of option value for environmental amenities was introduced by Burton A. Weisbrod and refined by Richard C. Bishop, Daniel A. Graham, and V. Kerry Smith. ${ }^{9-13}$ The option value concept arises when an individual is uncertain about whether he or she will make use of an environmental amenity. In the case of library reference desk services, the patron is uncertain about whether or how often the services will be desired. When uncertainty exists, ${ }^{14}$ the appropriate measure of the total value of the amenity is the ex ante value the individual's maximum willingness to pay for access to the amenity before the uncertainty about use is resolved. In the environmental economics literature, this ex ante value is called the "option price." Use value is an ex post measure of value, measuring the maximum willingness to pay for use of the amenity by the individual after the uncertainty is resolved. Option value of an environmental amenity is calculated as the difference between the ex post and ex ante measures (option price minus use value); hence, this measure estimates the value to nonusers. That some individuals have a positive option price but never exercise it (e.g., never appear at the reference desk) is irrelevant: it is the option price that is the appropriate measure of the benefits to users.

\section{Benefit Measurement and the Contingent Valuation Method}

The CV method, developed to measure the benefits of environmental amenities, provides the vehicle for accurate measurement of option prices for reference desk services. Consider first that reference desk services (as well as other library services) may be viewed as a quasi-private good, such as environmental amenities. Unlike pure private goods (bread, dishwashers, and so on) where the price at which a product is purchased reveals a lower bound on the benefit of the item to the consumer, quasi-private goods are not traded in an explicit market, and hence the benefit to the consumer, even a lower bound, is not immediately revealed. Moreover, quasi-private goods are goods for which there are collective property rights: all citizens of the United States "own" the Grand Canyon and have the right to visit it (provided they pay the cost of transportation and follow the rules set out for visitation, and so on). Similarly, members of a university "own" the right to use the library (under the restrictions the library imposes). But one cannot sell the property right to a quasi-private good.

Cost-benefit analysis requires accurate estimates of the values of goods and services. In some circumstances, the value of goods not explicitly traded in markets may be directly inferred from market transactions. Consider, for example, the value to individuals of lower levels of air pollution. Although there is no explicit market for cleaner air and hence no explicit WTP, one can infer WTP by comparing the prices of houses, and with the appropriate statistical model, extracting the premium that people are willing to pay for a house in an area with cleaner air (other housing characteristics constant). ${ }^{15,16}$ But in many instances, it is difficult to ascertain where valuations would be revealed in explicit markets, or because of the particular circumstances, the valuations in explicit markets would be incomplete. In such circumstances, a different method for estimating benefits is needed. 
$\mathrm{CV}$ is such a method. In CV, carefully designed surveys-unlike usual public opinion surveys-are used to elicit WTP for improvements (or WTP to avoid degradation) in a public good or quasi-private good. Because the theoretically ideal method for measuring benefits would be based on individual preferences revealed in market transactions, $\mathrm{CV}$ prescribes the construction of a hypothetical market in which the survey participant purchases (reveals his or her valuation of) the good in question.

Robert K. Davis, the originator of CV, believed that it was possible to "approximate a market" in a survey by giving a detailed description of the good and the specific changes under consideration. ${ }^{17}$ Note that the valuations are contingent upon the hypothetical market constructed by the researcher and the increments or decrements in providing the good. CV requires that the hypothetical market include a detailed description of the good indicating the character and quantity of the present provision level, variations in the level of provision, and the method by which the individual would pay for the good.

Murfin suspects that WTP may be difficult to estimate. ${ }^{18}$ There are many potential biases in estimating WTP. For example, respondents may overstate their true values if they wish to see more of the good in question provided. But such strategic thinking might lead respondents to understate their true value if they fear they will pay an individual-specific tax based on their stated value. Although there are many potential biases in estimating WTP, there is also a great deal of evidence on the validity of the CV method. Robert C. Mitchell and Richard T. Carson argued that "contingent valuation represents the most promising approach yet developed for determining the public's willingness to pay for public goods."19 They listed more than a hundred CV studies performed in the United States (and many more have been done since 1989). Christopher H. Green et al surveyed CV studies done in the United
Kingdom, and Stale Navrud surveyed CV studies done in Europe. ${ }^{20,21} \mathrm{CV}$ has been tested extensively and validated against other benefit measures.

There is another aspect of cost-benefit analysis, however, that librarians may regard as problematic. A fundamental principle of cost-benefit analysis is that the consumer knows his or her own interests best and that measures of the benefits and costs of a policy change must rely exclusively on the individual's valuations. Librarians may question this assumption, at least in some domains. They offer years of experience and education, and a holistic perspective when making decisions about how to allocate scarce resources. For example, part of the mission of most academic libraries is the archival role in preserving intellectual content, a mission that may not be uppermost in the minds of students and other patrons. Though the authors do not advocate sole dependence on patrons' valuations of various library services, they do think that the consumer sovereignty principle should hold for assessing the value of library reference desk services. Patrons are the only ones in the position to evaluate the worth of these services in their own particular circumstances (opportunity cost of time, knowledge, other sources of assistance, and so on).

\section{Institutional Setting and the Design and Implementation of the Survey}

Virginia Commonwealth University (VCU) is an urban, state-supported Carnegie Research I University, located in Richmond, Virginia. Total enrollment in the fall of 1996 was 21,681 students, with an annual FTE of 17,736 . The university has two physical campuses located two miles apart. The academic campus provides undergraduate and graduate education to 18,454 students in a wide variety of disciplines. The Medical College of Virginia campus provides health sciences programs to 3,227 students in five colleges and schools.

University Library Services (ULS) serves students and faculty on both cam- 


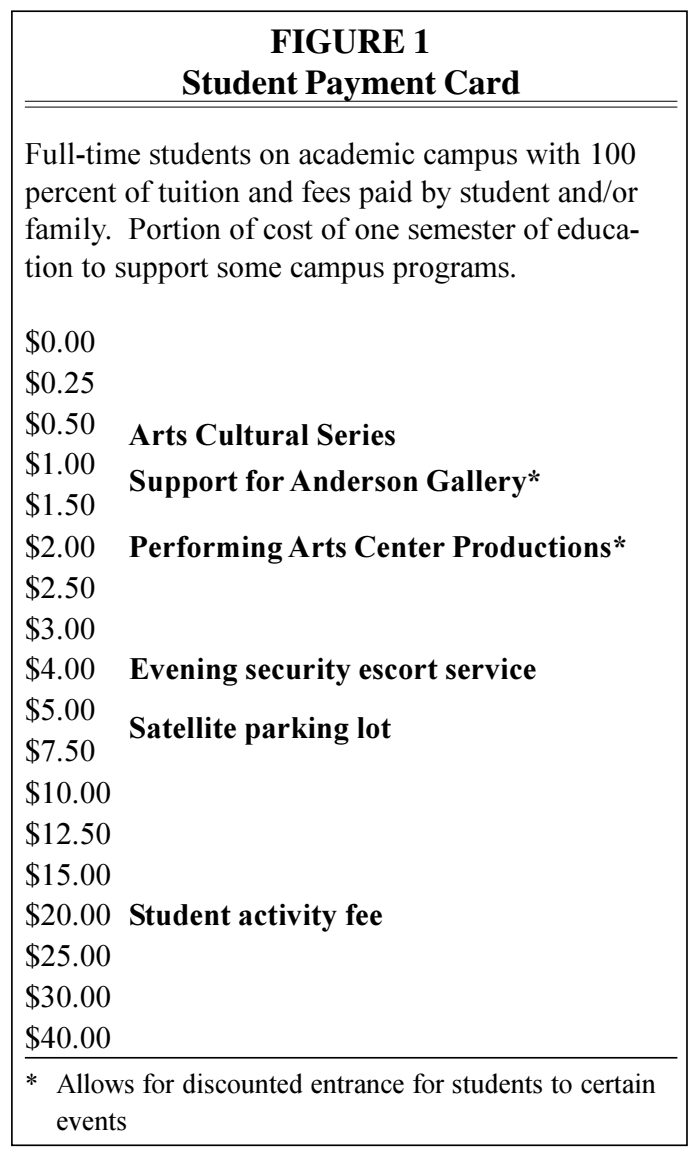

sisting of two, side-by-side workstations. Each workstation is equipped with a telephone and a personal computer mounted with the full array of library databases and navigation menus.

The following description conveys the essential elements of the CV survey design in this application. A random sample of students and instructional faculty from the academic campus was identified. The study results would have been critically flawed if only those patrons who actually entered the library or appeared at the desk had been surveyed. The VCU Survey Research Lab, a major survey research laboratory on the academic campus, reviewed the survey instrument and, with the oversight and cooperation of the principal investigators, trained the interviewers and administered the survey. The lab conducted all interviews during an eight-week period in the spring of 1997. Interviewers met with students and faculty in a convenient location (the student commons, the faculty member's office). Students who participated

puses primarily through two libraries. This study focuses on services provided by the James Branch Cabell Library to the students and 1,498 full-time instructional faculty on the academic campus-the principal beneficiaries of reference desk services. Unquestionably, noninstructional VCU staff and members of the general public derive benefit from these services as well. Nevertheless, the substantial added costs and logistical problems of sampling these populations prevented their being included in this study.

Reference desk services in Cabell Library are currently offered sixty-three hours per week during the academic year. The desk is almost entirely double-staffed during the fall and spring semesters and single-staffed during the summer and holiday sessions. Desk services are provided from a single reference counter con- were offered incentive payments of $\$ 10$ coupons for campus food services.

The survey is modeled after the freshwater quality CV survey in Mitchell and Carson. ${ }^{22}$ The complete survey for students is available at www.vcu.edu/busweb/economics/harless/harlessp.htm. The authors describe the survey for students and then indicate important differences in the survey for faculty. The interviewer begins the survey with questions about the library (e.g., frequency of use). The interviewer then indicates that the next series of questions concern "services provided by librarians at the Cabell Library, and how much those services are worth to you." He or she defines reference desk services and tells respondents that the questions concern reference desk services only, not collections, computerized databases, reference materials, or other materials in the 
library. The interviewer shows the student a picture of the reference desk and asks a number of questions concerning the student's use of it.

The interviewer then begins to construct the hypothetical market necessary to implement CV. Critical to constructing this market is the "payment card," which indicates approximately what the student pays for several other university services. Figure 1 shows the payment card for fulltime students with 100 percent of tuition and fees paid by the student and / or family. The interviewer asks the student to look at the payment card and explains that it shows the cost to the student per semester for specific services on the VCU campus. Note that the payment card indicates specific dollar amounts of the cost of one semester of education devoted to various programs: $\$ 20$ for a student activity fee, $\$ 6$ for free parking and bus service from a satellite parking lot, $\$ 4$ for an evening security escort service, and so on.

In the survey for students, six different payment cards were scaled appropriately for differences in the levels of grants and scholarships (but not loans) received by students. Students were shown a table indicating the cost of tuition and fees for one semester of study at VCU, and were asked: "Of your total bill for tuition, fees, and books, what percentage of the total bill is paid by you or your family out of pocket or paid by student loans that must be repaid later?" A student indicating that he or she and/or his or her family paid between 50 and 74 percent of the cost was then shown a payment card with the cost of services appropriately adjusted. For example, the student activity fee is shown to be $\$ 12.50(=((.50+.74) / 2) * \$ 20.00)$ rather than $\$ 20.00$. The justification for the adjustment of the price/cost of related services goes back to the logic of cost-benefit analysis, which mandates that goods and services have value because individuals are willing to sacrifice something to obtain them. The payment card is used to inform the individual about the price of particular services embedded in the price of tuition and fees. Students who receive scholarships and grants pay a lower price (sacrifice less), and hence the price of particular services is lower as well.

To create the hypothetical market and directly connect responses to payments, the interviewers told students: "To maintain the current level of other university services, reference desk hours can only be expanded if students pay higher tuition and fees. Likewise, if Cabell Library reference desk hours were cut, the savings could decrease student tuition and

\section{Interviewers then told students that they were going to ask about the value the student placed on refer- ence desk services and on the value, if any, of increasing the hours of services.}

fees." Interviewers then told students that they were going to ask about the value the student placed on reference desk services and on the value, if any, of increasing the hours of services. Students were further reminded of the link between their answer and their own tuition and fees: "Larger amounts on the payment card can increase your tuition and fees. Lower amounts represent lower tuition and fee payments. By choosing an amount for reference desk services, you have the opportunity to say how much those services are worth to you." After this extensive setup, students were asked their WTP: "Card 5 shows the current hours of operation of the Cabell Library and the current hours of operation of the Cabell Library reference desk; currently, the reference desk is open sixty-three hours per week. What amount on the payment card, or any amount in between, is the most you would be willing to pay in tuition and fees a semester to maintain the current hours of operation of the reference desk?"

All students were then introduced to proposal 1 in which the hours of operation of the reference desk would increase by eighteen hours a week (a visual aid indicated the exact additional hours). Students were asked: "In addition to the 


\begin{tabular}{|c|c|}
\hline \multicolumn{2}{|r|}{$\begin{array}{c}\text { FIGURE } 2 \\
\text { Instructional Faculty Payment Card }\end{array}$} \\
\hline \multicolumn{2}{|c|}{$\begin{array}{l}\text { Costs per calendar year to support some university } \\
\text { programs and services. }\end{array}$} \\
\hline \multicolumn{2}{|l|}{$\$ 0.00$} \\
\hline \multicolumn{2}{|l|}{$\$ 1.25$} \\
\hline \multicolumn{2}{|l|}{$\$ 2.50$} \\
\hline \multicolumn{2}{|l|}{$\$ 5.00$} \\
\hline$\$ 7.50$ & $\begin{array}{l}\text { Evening security escort service (cost per } \\
\text { student FTE and instructional faculty } \\
\text { member) }\end{array}$ \\
\hline \multicolumn{2}{|l|}{$\$ 10.00$} \\
\hline \multicolumn{2}{|l|}{$\$ 12.50$} \\
\hline \multicolumn{2}{|l|}{$\$ 15.00$} \\
\hline \multicolumn{2}{|l|}{$\$ 20.00$} \\
\hline \multicolumn{2}{|l|}{$\$ 25.00$} \\
\hline$\$ 37.50$ & $\begin{array}{l}\text { Library subscription cost for science, } \\
\text { social science, and arts \& humanities } \\
\text { citation indexes (cost per instructional } \\
\text { faculty member) }\end{array}$ \\
\hline \multicolumn{2}{|l|}{$\$ 50.00$} \\
\hline \multicolumn{2}{|l|}{$\$ 62.50$} \\
\hline$\$ 75.00$ & $\begin{array}{l}\text { Faculty/staff access fee for VCU recre- } \\
\text { ational facilities (an elective payment) }\end{array}$ \\
\hline$\$ 100.00$ & $\begin{array}{l}\text { VCU Faculty Grant-in-Aid Program (cost } \\
\text { per instructional faculty member) }\end{array}$ \\
\hline \multicolumn{2}{|c|}{$\$ 125.00$} \\
\hline \multicolumn{2}{|l|}{$\$ 150.00$} \\
\hline$\$ 200.00$ & \\
\hline
\end{tabular}

dent wished to make any changes. The WTP values after this opportunity to make changes are reported in the subsequent analyses. The final survey questions concern the participant (class status, college, and so on). Interviews closed with a debriefing in which the interviewer explained that the survey was intended to obtain the value the individual places on reference desk services, but that there were currently no plans to increase student tuition or fees to pay for the Cabell Library reference desk.

The structure of the survey for faculty is nearly identical to that for students. Most differences are minor. It is natural to ask students about WTP per semester and natural to ask faculty about WTP per year. However, one important difference is the payment vehicle. Although the student valuation question could be stated in terms of tuition and fees, the payment vehicle for faculty was necessarily less direct. Faculty are reminded that they pay for university and library services directly:

(\$ ) to maintain current hours, how much are you willing to pay to increase the hours of the reference desk as depicted in proposal 1?" Subjects who gave a non-zero dollar amount to either or both of the "maintain current hours" or proposal 1 questions were then asked their willingness to pay for proposal 2, which would increase reference desk hours by another 18.5 hours so that the reference desk would be open all the hours the library was open. Subjects who refused to answer ${ }^{23}$ one or both WTP questions or who answered "zero" or "nothing" were asked a supplementary question (described below).

After obtaining answers for the three WTP questions, the interviewer reviewed the WTP amounts and asked if the stu-

I want to remind you that as a faculty member you pay for services at VCU: You pay for services directly when you pay taxes. You pay for services indirectly when money is used for one purpose instead of another. Money used to pay for reference desk services is not available for other university services you may desire such as faculty development or travel to professional meetings. If Cabell reference desk hours were expanded, then there would be less money to provide other university services. Likewise, if reference desk hours were cut, the savings could be used to increase the levels of other university services. 
The survey for faculty also makes use of a payment card (see figure 2). The payment card for faculty includes one item also included on the student payment card (evening security escort service). The payment card also includes several items of interest to faculty: the library subscription cost for the social science, science, and arts and humanities citation indexes, a university grant in aid of research programs, and the access fee for VCU recreational facilities.

The survey ties faculty WTP responses directly to the faculty member's pocketbook: "Remember that larger amounts on the payment card represent higher direct and indirect costs to you. Lower amounts represent lower direct and indirect costs. By choosing an amount for reference desk services, you have the opportunity to say how much those services are worth to you." The WTP questions are stated in terms similar to that on the survey for students.

In contingent valuation studies, it is common to have some participants who, at least initially, refuse to answer or respond that their maximum WTP is zero as a protest response. The authors follow their model survey (Mitchell and Carson) in taking such respondents through a separate set of questions and statements in order to (1) induce them to participate if they have initially refused to answer and (2) separate a protest zero from genuine WTP of zero. Individuals who responded "zero" or "nothing," or who refused to answer the first two WTP questions, were asked a series of questions to identify the reason for their response. An affirmative response to "Did you say zero or nothing because that is what reference desk services are really worth to you?" is counted as a genuine WTP of zero. An affirmative response to any of the other questions (e.g., "Did you say zero dollars or nothing because you didn't realize you currently pay for reference desk services?") prompted the interviewer to read a short statement addressing the concern, reexplaining the WTP question, and inviting the respondent to answer the WTP question. Those who persisted in saying zero or nothing or refusing to answer were counted as "protest zeros."

\section{Findings}

The findings of the survey are summarized in tables 1 through 4 . Table 1 gives the summary of important information on use and attitudes toward the Cabell Library reference desk. Note that in some circumstances it was natural to phrase questions differently for students and faculty. Of the 84 percent of students in the sample who had used the services of the reference desk, the median response was that they used it two to five times per semester. The median response for faculty was that they used the services of the reference desk two to five times per year. Considerable variation in reference desk use was evident in responses (not reported in table 1): 17 percent of students reported using the reference desk six or more times per semester and 18 percent of faculty reported using it eleven or more times per year. Students and faculty overwhelmingly reported that they were either "very satisfied" or "satisfied" with the help received during the last encounter at the reference desk. The number of faculty reporting that they were "very satisfied" was considerably higher.

Both queuing and balking occur at the desk. Student and faculty responses indicated similar waiting time and instances of balking. As indicated in table 1, 20 percent of both students and faculty reported having to wait to speak to a librarian on all or most of their visits. But the time of day that patrons use the library must make a great deal of difference because 50 percent of students and 37 percent of faculty reported hardly ever or never having to wait to see a reference librarian. Interviewers asked (in separate questions) if patrons had ever gone to the reference desk intending to consult with a librarian but left because of a line or because the reference desk had closed. Faculty and students reported similar rates of balking, but students were twice as 


\begin{tabular}{|c|c|c|}
\hline \multicolumn{3}{|c|}{$\begin{array}{c}\text { TABLE } 1 \\
\begin{array}{c}\text { Summary Statistics on Frequency of Use and Satisfaction } \\
\text { with Reference Desk Service }\end{array} \\
\end{array}$} \\
\hline & Students & Faculty \\
\hline Sample size & 170 & 212 \\
\hline Median number of visits to Cabell Library per month & 5 & 3 \\
\hline Have used the services of the reference desk & $84 \%$ & $100 \%$ \\
\hline Frequency of use of reference desk, median response & $\begin{array}{c}2-5 \text { times/ } \\
\text { semester }\end{array}$ & $\begin{array}{c}2-5 \text { times/ } \\
\text { year }\end{array}$ \\
\hline \multicolumn{3}{|l|}{ Satisfaction with help received at last visit: } \\
\hline Very satisfied & $49 \%$ & $65 \%$ \\
\hline Satisfied & 42 & 25 \\
\hline Dissatisfied & 6 & 2 \\
\hline Very dissatisfied & 1 & 0 \\
\hline No answer & 1 & 7 \\
\hline \multicolumn{3}{|c|}{ Frequency of wait time to speak to reference desk librarian: } \\
\hline All of visits & $7 \%$ & $5 \%$ \\
\hline Most of visits & 13 & 15 \\
\hline Some of visits & 29 & 38 \\
\hline Hardly ever & 34 & 30 \\
\hline Never & 16 & 7 \\
\hline No answer & 1 & 6 \\
\hline \multicolumn{3}{|c|}{ Ever intended to consult with librarian but left because of a line: } \\
\hline Yes & $42 \%$ & $41 \%$ \\
\hline No & 57 & 56 \\
\hline No answer & 1 & 3 \\
\hline \multicolumn{3}{|c|}{ Ever intended to consult with reference librarian but found desk closed: } \\
\hline Yes & $33 \%$ & $16 \%$ \\
\hline No & 66 & 80 \\
\hline No answer & 1 & 4 \\
\hline \multicolumn{3}{|c|}{ Most important reason for having a reference desk: } \\
\hline Advice on where to start a research project & $7 \%$ & - \\
\hline Advice on how to use computerized databases & 15 & $8 \%$ \\
\hline Advice on searching the World Wide Web & 2 & - \\
\hline $\begin{array}{l}\text { Use librarians' specialized knowledge about finding } \\
\text { information }\end{array}$ & 42 & 46 \\
\hline Find out what is in the library and how to find it & 12 & - \\
\hline Even if don't need help now, I can use it when I do need help & $\mathrm{p} \quad 21$ & 15 \\
\hline Can assign research projects knowing students can get help & - & 27 \\
\hline $\begin{array}{l}\text { Don't use desk, but it is important that a university library } \\
\text { have a desk }\end{array}$ & - & 4 \\
\hline
\end{tabular}

likely to report having their intention of consulting with a reference librarian foiled by finding the desk closed.

Table 1 also shows the responses of students and faculty to a question on the most important reason for having a reference desk. Note that the options presented to students and faculty differed. Faculty were not presented with the response "I can get advice on where to start 
TABLE 2

\begin{tabular}{|c|c|c|c|}
\hline & \multicolumn{3}{|c|}{ Students (per semester) } \\
\hline & Current Hours & Proposal 1 & Proposal 2 \\
\hline Mean & $\$ 7.479$ & $\$ 4.012$ & $\$ 3.004$ \\
\hline Median & $\$ 5.000$ & $\$ 1.750$ & $\$ 1.000$ \\
\hline $10 \%$ trimmed mean & $\$ 5.593$ & $\$ 2.412$ & $\$ 1.368$ \\
\hline Standard deviation & $\$ 7.770$ & $\$ 4.337$ & $\$ 2.724$ \\
\hline $95 \%$ confidence interval & {$[\$ 4.472, \$ 6.715]$} & {$[\$ 1.786, \$ 3.038]$} & {$[\$ 0.975, \$ 1.762]$} \\
\hline Number of protest zeros/refusals & 3 & & \\
\hline \multirow[t]{3}{*}{ Excluded due to interviewer error } & 1 & & \\
\hline & \multicolumn{3}{|c|}{ Faculty (per year) } \\
\hline & Current Hours & Proposal 1 & Proposal 2 \\
\hline Mean & $\$ 60.006$ & $\$ 18.148$ & $\$ 11.299$ \\
\hline Median & $\$ 37.500$ & $\$ 5.000$ & $\$ 0.000$ \\
\hline $10 \%$ trimmed mean & $\$ 45.761$ & $\$ 9.371$ & $\$ 3.456$ \\
\hline Standard deviation & $\$ 46.385$ & $\$ 20.307$ & $\$ 11.261$ \\
\hline $95 \%$ confidence interval & {$[\$ 39.539, \$ 51.983]$} & {$[\$ 6.647, \$ 12.095]$} & [\$1.946, \$4.967] \\
\hline Number of protest zeros/refusals & 17 & & \\
\hline Excluded due to interviewer error & 1 & & \\
\hline Excluded due to confused response & 1 & & \\
\hline
\end{tabular}

a research project" (although they could have volunteered this response). Faculty were presented with additional responses (e.g., being able to assign research projects knowing students can get help at the reference desk). Note that students and faculty indicated that the most important reason for having a reference desk is to use the librarians' specialized knowledge about finding information. The number of patrons choosing this response and the response "Even if I don't need help now, when I do need future help finding materials in the library, I can go to the reference desk" indicates that the idea of option value for reference desk services is important in patrons' valuations of reference desk services.

Table 2 gives the most important information from the study: summary statistics for WTP for reference desk services. Recall that patrons were asked their WTP to maintain current reference desk hours, to increase reference desk hours by eighteen hours (proposal 1), and to increase reference desk hours by a further 18.5 hours (proposal 2). Recall as well that stu- dents were asked for WTP per semester, whereas faculty were asked WTP per year. The mean and median values to maintain current hours were $\$ 7.48$ and $\$ 5.00$ for students, and $\$ 60.00$ and $\$ 37.50$ for faculty. As expected, the distribution of WTP values is skewed: some patrons report very high values, some report a WTP of zero. In this circumstance, it seems appropriate to use a robust statistical procedure-the trimmed mean-to characterize central tendency. ${ }^{24,25}$ The 10 percent trimmed mean is calculated after 10 percent of the responses have been trimmed from both ends of the distribution. (The median is the $50 \%$ trimmed mean, and the ordinary mean is the $0 \%$ trimmed mean.) Table 2 shows the 10 percent trimmed means, standard deviation for the 10 percent trimmed mean, and the resulting 95 percent confidence interval for students and faculty at each of the three provision levels.

The trimmed mean for faculty WTP to maintain current hours, $\$ 45.76$ per year, is substantially higher than the value for students, \$5.59 per semester. But the 


\begin{tabular}{|lccc|}
\hline \multicolumn{4}{|c|}{ TABLE 3 } \\
Benefit-Cost Analysis of Reference Desk Services \\
on the VCU Academic Campus \\
\hline \multicolumn{4}{|c}{ Maintain } \\
& & \\
\hline & Current Hours & Proposal 1 & Proposal 2 \\
\hline Student benefit & $\$ 257,895$ & $\$ 111,185$ & $\$ 63,205$ \\
Faculty benefit & $\$ 68,548$ & $\$ 14,036$ & $\$ 5,183$ \\
Total benefit & $\$ 326,443$ & $\$ 125,221$ & $\$ 68,388$ \\
Total cost & $\$ 93,600$ & $\$ 25,300$ & $\$ 26,000$ \\
Benefit:cost & $3.5: 1$ & $4.9: 1$ & $2.6: 1$ \\
\hline
\end{tabular}

Using the 10 percent trimmed mean as the measure of central tendency, the authors estimated the aggregate value of the reference desk to the population of students and faculty and then summed valuations across students and faculty to get at the total value for students and

trimmed mean for proposal 1 and proposal 2 for faculty decreases precipitously compared to the decline for students. The median response from faculty for proposal 2 is zero, from which the authors surmise that faculty members do not expect to use the reference desk during these hours and expect that students should be able to use the reference desk during the day and early evening.

Table 2 also indicates that four subjects in the student sample and nineteen subjects in the faculty sample are not included in the willingness-to-pay summary statistics. As explained in the previous section, a certain number of individuals, at least initially, refused to respond to the WTP question or responded by saying "zero" or "nothing" as a protest. The survey design took these participants through a series of statements and questions to try to get at the reason for their response and to get them to state a value. Some refusals and protest zeros remained-three among students and seventeen among faculty. These are actually very low rates of refusals/protest zeros. ${ }^{26}$ A number of refusals among faculty members occurred at the point when the payment card was introduced; these faculty members were apparently unwilling to even consider trade-offs among different services on the campus. Two surveys were excluded due to interviewer error, and one survey was excluded because the faculty member responding remained confused about what was being asked (he apparently believed he was being asked how much a reference desk librarian should be paid). faculty. The total benefit and total cost for reference desk services could then be compared. For example, the authors estimated the total valuation per semester for current hours of the reference desk for students to be $(10 \% \text { trimmed mean })^{*}$ (number of students) $=\$ 5.59 * 18,454=\$ 103,158$. It was assumed that students value summer hours at a level one half the valuation of a semester. The aggregate value that students place on reference desk services for a calendar year is $\$ 257,895$. The authors made similar estimates of total value for faculty (given that there are 1,498 full-time instructional faculty) and for the two proposals. Table 3 gives the estimates of annual benefit for students and faculty.

\section{A number of refusals among faculty members occurred at the point when the payment card was introduced; these faculty members were appar- ently unwilling to even consider trade-offs among different services on the campus.}

Table 3 also presents estimates of the costs of reference desk service. At the VCU academic library, the direct cost of operating the reference desk consists largely of the cost of staff, plus small additional expenditures for phone service and computers for two workstations. Staff costs were calculated by gathering actual hours worked at the reference desk during representative months of 1997 for library faculty, staff, and students, and these hours were multiplied by respective average salary and wage rates. ${ }^{27}$ During these time periods, the desk was 
staffed by faculty librarians, staff, and students 39 percent, 52 percent, and 9 percent of the time, respectively. By projecting these figures over a 52-week period and adding ancillary costs, total costs to maintain current hours were estimated to be approximately $\$ 94,000$. Similarly, the total cost of staffing the desk the additional hours in proposals 1 and 2 were estimated at $\$ 25,300$ and $\$ 26,000 .{ }^{28}$ The benefits (ignoring benefits to other library patrons) of the current hours of reference desk service exceed the costs by a ratio of 3.5 to 1 ; the benefits of expanding hours as in proposal 1 exceed costs by a ratio of 4.9 to 1 .

Finally, the authors present evidence that option value is of fundamental importance in patrons' valuations. Table 4 shows summary statistics for respondents' total WTP for current hours, proposal 1, and proposal 2 by reported frequency of use of the reference desk. Table 4 shows that the eleven students (out of 166 total) who reported that they used the services of the reference desk more than ten times in a semester had a mean total WTP of $\$ 8.84$, a median of $\$ 5.50$, and a 10 percent trimmed mean of $\$ 7.92$. If one conceives the value of the reference desk to be limited to use value, it is incomprehensible that the total WTP is higher for students who have never used the reference desk or do not visit it in a typical semester. But the option value concept makes the WTP values sensible: non- or infrequent users know the reference desk exists, plan to use it when the need arises, and are willing to pay to ensure that the service will be available when the need arises. It also can be speculated that infrequent reference desk users are likely unsophisticated users of the library whose need (and hence WTP) is greater. The authors wish to make two final notes concerning table 4 . First, the authors do not claim that there are differences in total WTP by frequency of use; a robust statistical test (not reported here) suggests there is no statistically significant difference. Rather, it is the absence of differences in total WTP that reveals the im- portance of option value. Second, a similar pattern exists for faculty WTP and frequency of use, but separating use value and option value is more difficult for faculty because they use the reference desk indirectly when they assign students projects knowing that they will go there for help. The authors do not know a simple way to illustrate the option value for faculty.

\section{Conclusions}

The library literature is full of cost studies. Numerous studies have calculated the average cost per reference question by tallying numbers of reference questions and dividing the totals into estimated costs to provide the service. It is unclear what is gained by knowing the average cost to answer a reference question if there is no measure of benefit to the patron to which to compare cost.

It is far more useful (and challenging) to estimate the monetary benefit that patrons attach to reference desk service. This study attempted to measure patron benefit of reference desk service in one academic library. It attempted to measure total WTP for the option to use reference desk services using the contingent valuation (CV) method. The authors argue that the usual notion of value in the library literature, use value, underestimates the value of reference desk services to patrons because it ignores the value to potential users who place value on the option of seeking assistance in the event they desire such services. Rather than surveying users as they exited the library or left the reference desk, the study surveyed a random sample of the population of students and instructional faculty. To have done otherwise would have led to an important sample selection bias by ignoring those who valued the option to use the reference desk even if they did not appear at the reference desk for help within a given time period.

Using CV, this study shows that the average student on the academic campus of VCU values reference desk services at approximately $\$ 5.59$ per semester. The av- 


\begin{tabular}{|c|c|c|c|c|}
\hline \multicolumn{5}{|c|}{$\begin{array}{c}\text { TABLE } 4 \\
\text { Evidence on Option Value: Frequency of Use and Total } \\
\text { WTP for Students }\end{array}$} \\
\hline \multirow[b]{2}{*}{$\begin{array}{l}\text { Frequency of Use in } \\
\text { Typical Semester }\end{array}$} & \multirow[b]{2}{*}{ Frequency } & \multicolumn{3}{|c|}{$\begin{array}{l}\text { Total WTP for Current hours, } \\
\text { Proposal 1, and Proposal } 2\end{array}$} \\
\hline & & Mean & Median & $\begin{array}{c}10 \% \text { Trimmed } \\
\text { Mean } \\
\end{array}$ \\
\hline More than 10 visits & 11 & 8.841 & 5.5 & 7.917 \\
\hline $6-10$ visits & 12 & 16.479 & 7.5 & 12.050 \\
\hline $2-5$ visits & 69 & 16.498 & 7.5 & 10.820 \\
\hline 1 visit & 38 & 12.987 & 7.0 & 10.055 \\
\hline 0 visits* & 36 & 13.315 & 9.5 & 10.970 \\
\hline
\end{tabular}

erage member of the instructional faculty values this service at $\$ 45.76$ per year. No attempt was made to estimate the value that university staff and the general public place on reference desk service. Given reasonable assumptions about the cost of service, students and faculty place a value on the current hours of reference desk service that exceeds the cost by a ratio of 3.5 to 1 .

Although the general concept of willingness to pay can be found in the library literature on reference services, no one has measured value in the correct manneroption price. It is hoped that readers of this study will discover a new tool to use in measuring benefits derived from reference and other library services that in turn will provide additional insight on how libraries can effectively allocate scarce economic resources. For the results of this study to be most meaningful, it would be helpful to conduct cost-benefit analyses of all major services within the library. The study results suggest that the benefits of reference desk service exceed the costs by comfortable margins (factors of $3.5,4.9$, and 2.6 to 1 ), but it is possible that the patron benefits of other library resources and services exceed their cost by an even greater factor. Information on patron benefits can be used to help library administrators allocate resources within the library and may also be of use in making a case for additional resources to be directed to the library.

Many librarians have questioned the efficiency of reference desk service. During a time of strained resources for academic libraries, the question is legitimate. The image of a librarian or library staff person waiting at the desk for questions portrays an image of potential inefficiency. The notion of option value turns the image of potential inefficiency on end: students and faculty are willing to pay to have the reference desk open just in case they have a question. Consider an analogy to insurance. An insurance policy is not regarded as inefficient because a claim is not filed. Similarly, the reference desk should not be regarded as inefficient because a librarian is occasionally observed waiting at the desk for questions.

The authors are grateful to The Council on Library Resources for funding this research through a Mellon Small Grant on the Economics of Information. 


\section{Notes}

1. Karen S. Summerhill, "The High Cost of Reference: The Need to Reassess Services and Service Delivery," Reference Librarian 43 (1994): 71-85.

2. Marjorie E. Murfin, "Cost Analysis of Library Reference Services," in Advances in Library Administration and Organization, ed. Gerald B. McCabe and Bernard Kreissman (Greenwich, Conn.: JAI Pr., 1993), 1-36.

3. Keith Ewing et al, "Symposium on Reference Service. Is Traditional Reference Service Obsolete? [and] other," Journal of Academic Librarianship, 21, no.1 (Jan. 1995): 3-25.

4. James R. Kuhlman , "On the Economics of Reference Service: Toward a Heuristic Model for an Uncertain World," Reference Librarian 49/50 (1995): 25-43.

5. Murfin., "Cost Analysis of Library Reference Services."

6. Paul B. Kantor et al, Studying the Cost and Value of Library Services Final Report (New Brunswick, N. J.: Alexandria Project Laboratory, School of Communication, Information and Library Studies, Rutgers, State Univ. of New Jersey, 1995).

7. Paul B. Kantor, "What Bang for the Buck: Costs and Beneficial Impacts of Library Operations," in The Economics of Information in the 1990's, ed. Jana Varlejs (Jefferson, N.C.: McFarland and Co., Inc. Publishers, 1995), 24-44.

8. Kantor et al report on the distribution of WTP for a single use of any library service or resource, but the authors were unable to find a separately reported WTP for an instance of reference desk service.

9. Burton A. Weisbrod, "Collective Consumption Services of Individual-Consumption Goods," Quarterly Journal of Economics 78, no. 3 (Aug. 1964): 471-77.

10. Richard C. Bishop, "Option Value: An Exposition and Extension," Land Economics 58, no. 1 (Feb. 1982): 1-15.

11. Daniel A. Graham, "Cost-Benefit Analysis Under Uncertainty," American Economic Review 71, no. 4 (Sept. 1981): 715-25.

12. V. Kerry Smith, "Option Value: A Conceptual Overview," Southern Economic Journal 49, no. 1 (Jan. 1983): 654-68.

13. V. Kerry Smith, "Uncertainty, Benefit-Cost Analysis, and the Treatment of Option Value," Journal of Environmental Economics and Management 14, no.3 (Sept. 1987): 283-92.

14. A more careful statement would indicate that uncertainty must exist and markets are "incomplete" so that, for example, we cannot buy an actuarially fair insurance policy that pays an amount sufficient to obtain reference advice in the event we require it.

15. Horst O. Nourse, "Effect of Air Pollution on House Values," Land Economics 43, no. 2 (May 1967): 181-89.

16. Ronald G. Ridker and John A. Henning, "Determinants of Residential Property Values with Special Reference to Air Pollution," Review of Economics and Statistics 49, no.2 (May 1967): 246-57.

17. Robert K. Davis, "Recreation Planning as an Economic Problem," Natural Resources Journal 3, no. 2 (1963): 239--49.

18. Murfin, "Cost Analysis of Library Reference Service," 27.

19. Robert C. Mitchell and Richard T. Carson, Using Public Surveys to Value Public Goods: Contingent Valuation Method (Washington, D.C.: Resources for the Future, 1989), 2.

20. Christopher H. Green et al, "Economic Evaluation of Environmental Goods," Project Appraisal 5 (1990): 70-82.

21. Stale Navrud, Pricing the European Environment, (Oxford, Eng: Oxford Univ. Pr., 1992).

22. Mitchell and Carson, Using Public Surveys to Value Public Goods, appendix B.

23. The authors regarded the response "Don't know" as equivalent to refusing to answer.

24. Peter J. Bickel, and Kjell A. Doksum, Mathematical Statistics: Ideas and Concepts (San Francisco: Holden-Day, 1977).

25. Steven M. Stigler, "Do Robust Estimators Work with Real Data," Annals of Statistics 5 (1977): 1055-98.

26. Mitchell and Carson, Using Public Surveys to Value Public Goods, 34.

27. In cost-benefit analysis for a government policymaker, an adjustment is made for taxes because the government also receives revenue from taxes; here, the circumstances are different because the authors perform a cost-benefit analysis for the university and hence use the wages inclusive of employer-paid taxes.

28. Two assumptions may tend to understate actual costs. It was assumed that the library would pay the same wage and salary rate for staff who worked extended hours as for those who work current hours. It also was assumed that the library would not increase overall library staffing to provide the extended hours but would internally reallocate staff from other departments and shifts. If the library increased overall staff levels, it would incur additional costs of office space, training, equipment, and supplies. 